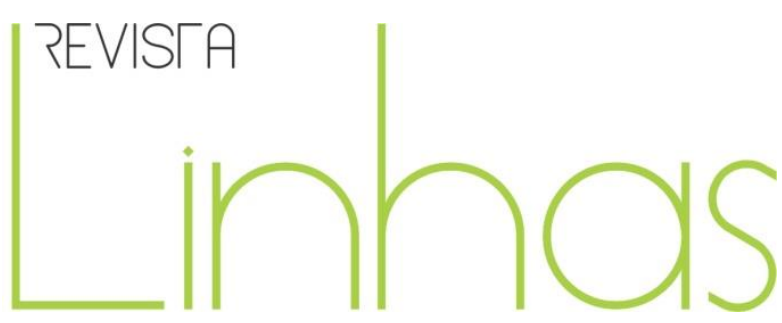

\title{
The relationship between religion and education in Brazil
}

\begin{abstract}
Taking into consideration a discussion on the relationship between religion and education in a laic country, and possible consequences of such relationship for society (DUARTE and NETO, 2013; EMMERICK, 2010; HAGOPIAN, 2006; MENDONÇA, 1995), this bibliographic paper aims at investigating possible effects or consequences of religion on education in Brazil. For such purposes, a literature review was conducted, resulting in 13 studies. The Meta-analysis approach (GLASS, MCGAW, SMITH, 1981) was adopted for data analysis. Results reveal that schools still perpetuate and legitimize a catholic discourse. Moreover, religion has proven to influence decisionmaking, self-esteem, academic performance and other issues.
\end{abstract}

Fábio Henrique Rosa Senefonte Universidade Estadual do Norte do Paraná - UENP - Cornélio

Procópio/PR - Brasil fabiosenefonte@uenp.edu.br

Keywords: Religion. Education. Brazilian Context.

\section{Para citar este artigo:}

SENEFONTE, Fábio Henrique Rosa. The relationship between religion and education in Brazil. Revista Linhas. Florianópolis, v. 19, n. 40, p. 434-454, maio/ago. 2018. 


\title{
A relação entre religião e educação no Brasil
}

\begin{abstract}
Resumo
Levando em consideração a discussão sobre a relação entre religião e educação em um estado laico, e as possíveis consequências de tal relação para a sociedade (DUARTE e NETO, 2013; EMMERICK, 2010; HAGOPIAN, 2006; MENDONÇA, 1995), a presente pesquisa bibliográfica objetiva investigar possíveis efeitos da religião sobre a educação no Brasil. Para tais finalidades, foi conduzida uma revisão da literatura, resultando em 13 estudos. O método da meta-análise (GLASS, MCGAW, SMITH, 1981) foi utilizado para análise de dados. Os resultados apontam que as escolas ainda perpetuam e legitima um discurso católico. Além disso, religião influencia na forma como as pessoas tomam decisões, na autoestima, desempenho acadêmico entre outras questões.
\end{abstract}

Palavras-chave: Religião. Educação. Contexto Brasileiro. 


\section{Introduction}

Religion has had a delicate connection with society in such an intricate relationship that they influence and are influenced by one another. Consequently, some religious precepts have been resignified in accordance with social advances and progress; however, on the other hand, religion has greatly influenced social spheres and people's cognition as well. Here cognition is conceptualized as what one knows, believes, thinks and does (BORG, 2003).

The history of the Brazilian society shows an enforced relationship between the Catholic Church and the government. Although, Brazil has a laic constitution, that is, with no religious involvement, Catholicism has had a strong influence on educational and political issues since the period of colonization. In this respect, religion is ubiquitous in several social spheres and in order to disseminate certain ideologies, it uses many vehicles, such as: inter alia, the media, churches, and schools.

Taking this into consideration, this bibliographic paper aims at reviewing the literature regarding studies on the relationship between education and religion in Brazil, which in turn is a laic country. Furthermore, I endeavor to investigate possible effects/ corollaries of such relationship on education in Brazil.

For the aforementioned purposes, I conducted a literature search and 13 studies were found and, therefore, are analyzed for this paper...

That being said, this paper is structured in the following order: a theoretical section that bespeaks the connectedness between the Catholic Church and political/educational issues throughout the history of Brazil. Then, I provide some methodological issues, including the nature, context, data collection and analysis of this investigation. The following section concerns the discussion of each study found; and at the end, I present some final considerations. 


\section{Religion and Education}

Defining religion proves to be challenging, given that such topic can be understood/analyzed from different perspectives, such as: philosophical, sociological, psychological view and many others. In addition, its origin is quite uncertain, so the study of religion becomes a very intricate field. According to its etymology (religionem, from Latin), religion refers to a belief, worship, respect or reverence for God or gods, which in turn are considered to be sacred (DURKHEIM, 1976). This etymology is also germane to law, lecture, teaching and relics. This origin helps us grasp the pedagogical characterization of religion throughout the Brazilian history, as illustrated in the following paragraphs.

Moreover, religion can be perceived as a very powerful system of beliefs and ideologies that motivates, persuades people (adherents) to act in a certain way in the world: it dictates the way people live and think, the way parents raise their children and so forth (EMMERICK, 2010; MENDONÇA, 1995). Additionally, religion plays a crucial role in people's decision-making, social interactions and in several human activities (SANTIAGO, SILVA, BARROSO, 2009). With such considerations in mind, it becomes clear that religion goes beyond an individual dimension (a private belief). As a matter of fact, it is a social phenomenon that may encompass a whole society.

In Brazil (focus of this study), religion has been part of society since the colonization by Portugal in the 1500s. Such colonization entailed the process of acculturation, in which the colonized (Native Brazilians) was expected to assimilate the colonizer's (Portuguese people) culture. In other words, Portuguese culture was imposed on the Brazilian indigenous population.

Suffice it to say, religion was one aspect of the Portuguese culture, more specifically the Catholic religion (having the Bible as its main doctrine), which was the official religion for several decades in Brazil. Moreover, other religions did not have the same prestige as the Catholic did. Such assumption is asserted in the Brazilian Constitution of $1824,5^{\text {th }}$ article: "The Roman Catholic Apostolic Religion will continue to be the Empire's Religion. All other religions are allowed as a domestic worship or in 
private homes designed for such purposes; and under no circumstances, outside of the temple" (translated').

Hence, the indigenous were converted to Christianity (FERNANDES, 2008; SANTOS, 2011, SILVA, 2008). Catholicism was God's work whereas indigenous' religions were considered devil's (SAVIANI, 2005). Such ideology legitimized the practices of catechism by Jesuits in the first centuries of the Brazilian Colony. In this regard, 'unreligious' people were frown upon since religion was seen as a basis for an individual's conduct. Although other religious perspectives (such as Protestantism, for instance) permeated and have permeated the Brazilian context, the Catholic Church has occupied a hegemonic position in Brazil, which is a Christian society seeing that studies have shown the majority of the population is declared as Catholic (BRUNEAU, 1973, MENDONÇA, 1995).

In the first decades after colonization, education was delegated to the Catholic Church because of its ecclesiastic hegemony. So, the Church, as an institution, used education (and other means) as a vehicle to propagate its beliefs and it was also concerned with its own preservation and expansion (HAGOPIAN 2006; MAINWARING, 1986, SOUZA et. al., 2002).

The religious-oriented schooling system promoted oppression, exclusion and discrimination, since it supported the domination by the bourgeoisie; therefore, schools were available only for the elite (powerful groups). Consequently, education was a synonym for power and prestige (SCHWARTZMAN, 1986). Nonetheless, it is imperative to emphasize that this power and prestige brought limitations. On the one hand, it is true that people who were educated had more power and prestige; on the other, they were unconsciously shaped by stronger forces (religious and political ideologies).

Ergo, the history of education in Brazil is marked by oppression, separatism and other principles that contradict the contemporary perspectives on education, which upholds egalitarian principles and emancipation of individuals through education (FREIRE, 1996; KISRT; WIRST, 2009).

\footnotetext{
1 “A Religião Católica Apostólica Romana continuará a ser a Religião do Império. Todas as outras Religiões serão permitidas com seu culto domestico, ou particular em casas para isso destinadas, sem forma alguma exterior do Templo".
} 
Nowadays, it is well known that education in Brazil is a responsibility of the government. Nevertheless, there is still a substantiated tie between the Church and educational and other political spheres, which proves to be a controversy, as Brazil has been a laic country since 1891 . Such secularist concept denotes total neutrality with regard to religion. The Brazilian Constitution of 1988 ( $19^{\text {th }}$ article, I) prescribes the following:

It is forbidden for the Union, the States, the Federal District and Municipalities: I - establish religious cults or churches, subsidize them, embarrass them, or maintain with them or their representatives dependency relationships or alliance, except in the form of law, the collaboration of public interest. (translated ${ }^{2}$ )

Although the concept of secularism is clear, in the current Brazilian Constitution, religious education is part of the curriculum for secondary and high school, as prescribed by the 'Education Guidelines and Framework Law' (LDB', 1996, 33 ${ }^{\text {rd }}$ article, I and II).

Art. 33. Religious education, facultative enrolment, is an integral part of citizens' education and constitutes as a school subject in normal hours of public elementary schools, ensured respect for religious diversity in Brazil, being prohibited any form of proselytizing. (Law No. 9475 of 22.7.1997)

$\S 1$ The school systems will govern the procedures to define the contents of religious education and will establish the rules for qualification and admission of teachers.

$\S 2$ The school systems will hear civil entities constituted by different religious denominations to define the contents of religious education. (translated ${ }^{4}$ )

\footnotetext{
2 É vedado à União, aos Estados, ao Distrito Federal e aos Municípios: I - estabelecer cultos religiosos ou igrejas, subvencioná-los, embaraçar-lhes o funcionamento ou manter com eles ou seus representantes relações de dependência ou aliança, ressalvada, na forma da lei, a colaboração de interesse público."

3 Acronym in Portuguese for "Lei das Diretrizes e Bases da Educação" (1996).

${ }^{4}$ Art. 33. O ensino religioso, de matrícula facultativa, é parte integrante da formação básica do cidadão e constitui disciplina dos horários normais das escolas públicas de ensino fundamental, assegurado o respeito à diversidade cultural religiosa do Brasil, vedadas quaisquer formas de proselitismo. (Redação dada pela Lei $n^{\circ}$ 9.475, de 22.7.1997).

$\S 1^{\circ}$ Os sistemas de ensino regulamentarão os procedimentos para a definição dos conteúdos do ensino religioso e estabelecerão as normas para a habilitação e admissão dos professores.

$\S 2^{\circ}$ Os sistemas de ensino ouvirão entidade civil, constituída pelas diferentes denominações religiosas, para a definição dos conteúdos do ensino religioso.
} 
Needless to say, the government finances religious education in Brazil. Therefore, such practice contradicts the federal constitution in view of the fact that a laic state is supposed to neither promote nor sponsor any religion.

According to the aforementioned law, religious education seeks to promote values and principles of citizenship. Additionally, schools should respect religious diversity and, therefore, they cannot induce someone to a particular religion. Hence, religious education cannot be confused with Catholic education. Moreover, assuming that religious education in Brazil encompasses all the religions in the country is rather naïve or utopic. Certain religions are expressively more prestigious than others, this in turn might lead to a biased religious education. Furthermore, it is relevant to stress that some hegemonic religions (the catholic, for example) condemns vehemently practices from other religions, especially Spiritism and the African ones.

Besides, the prescriptions in the Law do not correspond to the reality in some schools. The enormous influence of the Catholic Church in Brazil leads teachers and schools to bias religious classes for a Catholicism class rather than a religious class, as it should be. Thus, it is noticeable the pervasiveness of Catholic symbols (crucifix, saints or images) and prayers (Our Father, Hail Mary and others) in several schools across the country (DUARTE; NETO, 2013). Moreover, Brazil has some Catholic-based holidays, which in turn proves how influential religion is in the country.

Once I exposed the theoretical framework, the next section illustrates the methodological procedures conducted in this paper.

\section{Methodological Issues}

This paper is a bibliographic study, whose focus is on the relationship between education and religion in Brazil. My concern is on an investigation of possible effects or consequences of religion on education, which entails individuals (students, teachers, school principals and religious people). Therefore, I adopt a qualitative nature, given that this paper covers a discussion on a social phenomenon, with particular individuals in a certain context (STRAUSS; CORBIN, 1998). 
For data collection purposes, I utilized the major scientific databases in Education: Google Scholar ${ }^{5}$, ERIC 6 , CAPES ${ }^{7}$ (dissertations, thesis and journals) and SciELO ${ }^{8}$. The scope for the search included all the research carried out both in Brazil and internationally without delimitation of time period and including all educational levels (from kindergarten to higher education). Hence, the search was undertaken both in Portuguese and in English; the following search terms were employed: "The effects of religion on education in Brazil", "the relationship between religion and education in Brazil" and "The consequences of religion on education in Brazil”. The counterparts in Portuguese are: “Os efeitos da religião na educação no Brasil”, "A relação entre religião e educação no Brasil” and "As consequências da religião na educação no Brasil".

This way, the literature search occurred between August and December of 2016 and originally resulted in 81 studies $^{9}$. In order to narrow the scope down, only empirical ${ }^{10}$ research was chosen, that is, research with data/ corpus analyzed. After such filter, only 13 studies remained.

Furthermore, my data analysis seeks to combine and contrast the different results produced in the 13 studies found. Therefore, the Meta-analysis approach (GLASS, MCGAW, SMITH, 1981) underpins the data discussion of this study.

After exposing the methodological procedures of this paper, the next section covers the discussion and analysis of such studies.

\section{Data Discussion}

As previously mentioned, the literature search conducted for this paper resulted in 13 studies. Regarding the educational level of each investigation, the studies can be grouped into two categories: Basic education (secondary and high school) and higher education. Such studies are scrutinized in the following subsections.

\footnotetext{
${ }^{5}$ The first 20 pages were scrutinized.

${ }^{6}$ Educational Resources Information Center <https://eric.ed.gov>.

7 Coordination for the Improvement of Higher Education in Brazil, available at <http://bancodeteses.capes.gov.br> and <http://www.periodicos.capes.gov.br>.

${ }^{8}$ Scientific Electronic Library Online <http://www.scielo.org/php/index.php>.

${ }^{9}$ I selected only studies whose foci were on education (scope of this research).

${ }^{10}$ Documentary and bibliographic studies (literature reviews) were not examined.
} 


\subsection{Basic Education}

7 out of the 13 studies found investigated secondary and high school, as illustrated in table 1:

Table 1: Empirical research on religion and education (Basic Education)

\begin{tabular}{|c|c|c|c|}
\hline Study & Focus & Results & Methods \\
\hline $\begin{array}{c}\text { Cunha and Barbosa } \\
\text { (2011) }\end{array}$ & $\begin{array}{l}\text { Analysis of the } \\
\text { teaching-learning } \\
\text { process during } \\
\text { religion classes in } \\
\text { secondary school }\end{array}$ & $\begin{array}{l}\text { Students are open to } \\
\text { religion diversity, but } \\
\text { some prejudice can be } \\
\text { identified in their } \\
\text { attitudes towards } \\
\text { unknown religions }\end{array}$ & $\begin{array}{l}\text { Class observation } \\
\text { and structured- } \\
\text { questionnaires }\end{array}$ \\
\hline Kuhn (2014) & $\begin{array}{l}\text { Discussion on } \\
\text { possibilities of } \\
\text { religious education in } \\
\text { high school }\end{array}$ & $\begin{array}{c}\text { Religious Education } \\
\text { should be included in } \\
\text { High school }\end{array}$ & Questionnaires \\
\hline Leite (2015) & $\begin{array}{c}\text { Proposal of a } \\
\text { pedagogical } \\
\text { intervention focusing } \\
\text { on religious diversity }\end{array}$ & $\begin{array}{c}\text { Religion should be } \\
\text { seen as a part of a } \\
\text { certain culture, an } \\
\text { individual expression }\end{array}$ & $\begin{array}{l}\text { Action research } \\
\text { (activities } \\
\text { performed in } \\
\text { class) }\end{array}$ \\
\hline Lima (2015) & $\begin{array}{l}\text { Teachers' attitudes } \\
\text { towards the } \\
\text { relationship between } \\
\text { the Catholic Church } \\
\text { and the pedagogical } \\
\text { practices in a } \\
\text { secondary school }\end{array}$ & $\begin{array}{c}\text { Teachers reproduce a } \\
\text { conservative religious } \\
\text { discourse, which } \\
\text { maintains a } \\
\text { sociocultural } \\
\text { segregation as to } \\
\text { black students }\end{array}$ & $\begin{array}{c}\text { Case study (semi- } \\
\text { structured } \\
\text { interviews) }\end{array}$ \\
\hline Maia e Silva (2012) & $\begin{array}{l}\text { Teachers' and } \\
\text { students' perceptions } \\
\text { of religion education } \\
\text { in high school }\end{array}$ & $\begin{array}{l}\text { Teachers employ } \\
\text { catholic-oriented } \\
\text { textbooks in classes. }\end{array}$ & $\begin{array}{c}\text { Ethnography } \\
\text { (observation and } \\
\text { interviews) }\end{array}$ \\
\hline
\end{tabular}




\begin{tabular}{cccc}
\hline Silva (2011) & $\begin{array}{c}\text { Investigation of } \\
\text { religion classes in a } \\
\text { secondary school }\end{array}$ & $\begin{array}{c}\text { Pedagogical practices } \\
\text { violate educational } \\
\text { laws, since only } \\
\text { Catholicism is } \\
\text { legitimized in school }\end{array}$ & $\begin{array}{c}\text { Semi-structured } \\
\text { interviews }\end{array}$ \\
\hline Tomaz (2012) & $\begin{array}{c}\text { The pedagogy of } \\
\text { religious education in } \\
\text { full-time schools }\end{array}$ & $\begin{array}{c}\text { A traditional, } \\
\text { excluding and } \\
\text { discriminatory model } \\
\text { permeates religion }\end{array}$ & Semi-structured \\
& classes & \\
& & & \\
& &
\end{tabular}

Source: the author.

Cunha and Barbosa (2011) aimed at exploring the teaching-learning process concerning religion education in a secondary school. $6^{\text {th }}$ and $7^{\text {th }}$ graders were interviewed and their perceptions reveal ambivalent views: on one hand, students clearly recognize the importance/ necessity of respecting religious diversity; on the other, some prejudice and stereotypes against unknown religions are still pervasive in students' attitudes.

Kuhn's research (2014) investigated teacher's opinion about the inclusion of religious education in high school, given that such education is offered only for elementary and secondary grades. Results point to a unanimous acceptance of such initiative. Teachers' arguments are profoundly based on religious ideologies (Catholic). In this case, the author advocates for the inclusion of religious education in high school. Nonetheless, the author's argumentation seems to be fragile since Kuhn just states that values and principles should be promoted:

Enabling religious education in schools is a duty of the ones who are responsible for educating free and aware citizens. Educating human beings, as social individuals, committed to the construction of the world is also to educate them to values that transcend the material existence. (KUHN, 2014, p. 6, translated ${ }^{11}$ )

\footnotetext{
${ }^{11}$ Oportunizar a formação religiosa nas escolas é dever de quem se propõe a formar cidadãos livres e conscientes. Formar o ser humano enquanto ser social, comprometido com a construção do mundo, é educá-lo, também para os valores que transcendem a sua existência material.
} 
The study lacks a discussion and strong argumentation that can support such view. Moreover, it is of paramount importance to take into account what parameter/criteria one should be based on when considering such values and principles. Furthermore, some questions need to be answered: What about people who are not engaged in any religion? Will they lack the values and principles religious people have?

Leite (2015) conducted action research, whose aim was to propose a pedagogical model to tackle religious diversity in a high school. The model consisted of 12 classes, with activities focusing on current social issues: identity, conflicts/violence, prejudice and so on. The author contends that because of a solid religious diversity in the school, some students seem rather resistant to the proposal. Leite (2015) purports that religion classes should not aim at debating religion; instead, such classes should provide "a grasp of different ways to be and live in the world" (p.33-34), as religion should be understood as part of a certain culture.

In her case study, Lima (2015) interviewed Art, History and Religion teachers in a secondary school in order to grasp their attitudes and pedagogical practices, taking into consideration the relationship between religion and education. The author concluded that Catholicism is hegemonic in the school investigated; and such hegemony brings some effects on the school practices: the school glosses over topics on diversity (religious, gender, etc.) and ethnic subordination and hierarchy are naturalized practices, which culminates in a marginalization of black students, for instance.

Maia e Silva (2012) undertook an ethnographic study aiming at investigating teachers' and students' perceptions of religious education in a public school. Results reveal that the (catholic) teachers investigated tend to use catholic-oriented materials in class. Under no circumstances are minority religions covered in the religion classes observed. The classes focused on evangelical and catholic teachings, which make some students unsatisfied and uninterested, since there was religious heterogeneity in class.

Seeking to investigate how religion classes in a secondary school eventuated, Silva (2011) conducted an investigation with three religion teachers. The analysis indicates that religion education in that school infringes educational laws since religion classes are wholly catholic-oriented and overlook any other religion. 
In her master's thesis, Tomaz (2012) examined how the pedagogy of religious education is organized in five full-time public schools. Through interviews, teachers, students and principals were participants of the research. The findings of the study show that the schools investigated perpetuate a traditional, excluding and discriminatory model in religion classes.

After an overview of the 7 studies focusing on secondary and high school, the next part of this section covers investigations whose context was higher education.

\subsection{Higher Education}

The other 6 studies found cover higher education, as shown in table 2:

Table 2: Empirical research on religion and education (Higher Education)

\begin{tabular}{|c|c|c|c|}
\hline Study & Focus & Results & Methodology \\
\hline Briggs (2011) & $\begin{array}{c}\text { The relationship } \\
\text { between religion and } \\
\text { higher education }\end{array}$ & $\begin{array}{c}\text { Non-religious } \\
\text { students: a discredit } \\
\text { on Bible } \\
\text { Religious students: } \\
\text { reinforcement of } \\
\text { religiosity }\end{array}$ & Questionnaires \\
\hline Carvalho et al. (2012) & $\begin{array}{l}\text { The influence of } \\
\text { religion on higher } \\
\text { education } \\
\text { (universities) }\end{array}$ & $\begin{array}{c}\text { Influence of religion } \\
\text { on students } \\
\text { integration of } \\
\text { scientific and religious } \\
\text { knowledge }\end{array}$ & Questionnaires \\
\hline $\begin{array}{c}\text { El-Hani; Sepulveda } \\
\text { (2009) }\end{array}$ & $\begin{array}{l}\text { Religion in higher } \\
\text { education }\end{array}$ & $\begin{array}{l}\text { influence of religion } \\
\text { on the student's } \\
\text { perceptions of nature } \\
\text { (world) } \\
\text { integration of } \\
\text { scientific and religious } \\
\text { knowledge }\end{array}$ & $\begin{array}{c}\text { Semi-structured } \\
\text { interviews }\end{array}$ \\
\hline
\end{tabular}




\begin{tabular}{|c|c|c|c|}
\hline $\begin{array}{l}\text { Santiago, Silva, } \\
\text { Barroso (2009) }\end{array}$ & $\begin{array}{l}\text { The influence of } \\
\text { religion on higher } \\
\text { education }\end{array}$ & $\begin{array}{c}\text { religion leads to lack } \\
\text { of autonomy and } \\
\text { influences on } \\
\text { people's decision- } \\
\text { making }\end{array}$ & $\begin{array}{c}\text { Semi-structured } \\
\text { interviews and } \\
\text { questionnaires }\end{array}$ \\
\hline $\begin{array}{l}\text { Schillinger-Agati; } \\
\text { Lind (2003) }\end{array}$ & $\begin{array}{c}\text { University students' } \\
\text { perceptions of } \\
\text { morality }\end{array}$ & $\begin{array}{l}\text { Religion-oriented } \\
\text { students } \\
\text { Catholic Influence }\end{array}$ & Questionnaires \\
\hline Souza et al. (2014) & $\begin{array}{l}\text { The influence of } \\
\text { religion on medicine, } \\
\text { psychology and } \\
\text { education }\end{array}$ & $\begin{array}{l}\text { Religion influences on } \\
\text { the student's self- } \\
\text { esteem and academic } \\
\text { performance }\end{array}$ & Questionnaires \\
\hline
\end{tabular}

Source: the author.

Briggs (2011) exposes an investigation conducted in a university and results show that non-religious students tend to discredit the Bible and religion. Conversely, however, religious students reinforce their religious beliefs and values. In this case, one can notice that the university is a powerful context that helps individuals to form their own ideologies. Results indicate that although religion tends to distance itself from science in a university context, students still maintain and reinforce their religious views. Here, I deem that it is necessary to take some questions into account: the study lacked a deeper analysis concerning the reason why students tend to discredit the Bible (probably on account of some inconsistencies between the Biblical premises and scientific discoveries). Furthermore, it is vital to consider students' major, since results may vary according the area of knowledge.

Santiago, Silva, Barroso (2009), carried out a study with university students concerning the influence of religion on their lives. Findings reveal that the relationship between religion and higher education may lead to a lack of autonomy as well as low selfesteem. These considerations are expressed by one student investigated: "I feared to make my own choices, not much because of people, but because I was taught that there is a being that, wherever you are, in whatever situation, keeps an eye one you, this being 
is God" (SANTIAGO, SILVA, BARROSO, 2009, p.10, translated ${ }^{12}$ ). The excerpt indicates that religion can inhibit one from making decisions especially when they go against religious tenets. With this in mind, it is understandable how autonomy, self-esteem and decisionmaking might be affected.

Besides decision-making, findings also bespeak impacts on students' social interactions:

Even today, I find it difficult to interact with someone more intimately, I cannot indulge in a relationship as I would like to. When I'm with my friends having fun and I drink some kind of drink that the church does not permit, I get suspicious, even if no more ties with the church, it is as if I was doing something wrong (SANTIAGO, SILVA, BARROSO, 2009, p.11, translated ${ }^{13}$ )

As adduced in the introduction of this paper, inasmuch as religious ideologies influence individuals' cognition, their social practices reflect the way they think, believe and know of something (BORG, 2003).

Although Carvalho et al. (2012), El-Hani; Sepulveda (2009), Schillinger-Agati; Lind (2003) and Souza, et al. (2014) carried out disparate studies, including different individuals, results are similar and ergo, I expose them altogether in this paragraph. Hence, such studies confirm the delicate influence of religion on university student's lives and this influence may affect the student's academic performance. Even though this is a very important result, the studies do not demonstrate how the student's academic performance is influenced by religion or lack of religion. Furthermore, none of the studies discuss whether the academic performance is good or not based on religion.

Additionally, the 4 studies signalize an integration of religious and scientific knowledge. University students usually assimilate a scientific discourse/ knowledge, which in turn tends to distance itself from the religious one. Religious university students,

\footnotetext{
12 "Eu tinha medo de fazer as minhas próprias escolhas, nem tanto por conta das pessoas, mas porque me ensinaram que existe um ser que onde quer que você esteja em qualquer situação está de olho em você, e esse ser é Deus."

13 "Ainda hoje, tenho dificuldade em me relacionar com alguém de forma mais íntima, não consigo me entregar da maneira que gostaria na relação. Quando estou com meus amigos me divertindo e bebo algum tipo de bebida que a igreja não permite, fico desconfiada, mesmo não tendo mais vínculo com a igreja, como se estivesse fazendo algo de errado."
} 
however, assimilate scientific knowledge and at the same time, maintain their religious one. Thus, students use scientific knowledge to complement the religious one. For instance, (religious) biology students investigated in El-Hani; Sepulveda (2009) believe that the origin of the life comes from God (religious knowledge); however, they believe in the evolution of the species (scientific knowledge).

The last part of this section comprises some discussions over the findings of the studies examined.

\subsection{Discussion}

As we can notice, scant attention has been placed on the relationship between religion and education with regard to empirical research, as only 13 studies were found. As displayed in table 3, South region has a slight advantage over the others as to conduction of research. Nonetheless, there seems to be a balance among the other regions.

Table 3: Where studies on education/religion have been conducted in Brazil

\begin{tabular}{cc}
\hline Region & Study \\
\hline North & Silva (2011) \\
\hline Northeast & El-Hani; Sepulveda (2009) \\
& Santiago, Silva and Barroso (2009) \\
\hline Midwest and the Federal District & Leite (2015) \\
\hline Southeast & Souza et al. (2014) \\
& Carvalho et al. (2012) \\
& Cunha and Barbosa (2011) \\
& Maia e Silva (2012) \\
South & Lima (2015) \\
& Souza, et al. (2014) \\
Undetermined & Kuhn (2014) \\
\hline & Briggs (2011) \\
\hline
\end{tabular}

Source: the author. 
Apropos of the studies examined, some assumptions can be considered as to secondary and high school:

a) Despite the fact that Brazil is a laic country, religious education is part of the curriculum for basic education. Hence, debating the unconstitutionality of religious education might be futile. Rather, a discussion on the effects/influence of religion on education is crucial. Moreover, such effects need to be evaluated whether they are beneficial or not. Besides that, religion education should include current social issues rather than focusing on certain religions (LEITE, 2015; TOMAZ, 2012);

b) Even though any form of proselytizing is forbidden, a large number of schools still perpetuate and legitimize a catholic discourse: catholic-oriented classes, catholic teachers and so on. As a corollary of such practice, Catholicism has been hegemonic (LIMA, 2015; MAIA E SILVA, 2012; SILVA, 2011; TOMAZ, 2012);

c) Although people are cognizant of religion diversity, because of the hegemony of Catholicism, minority religions are marginalized and stigmatized (CUNHA; BARBOSA, 2011).

Vis-à-vis religion in higher education, we can assume:

a) The vast majority of the population is considered as catholic. In this aspect, there is a significant number of religious university students. Hence, there seems to be an integration of religious and scientific knowledge, even though both entities have divergent views on several issues (CARVALHO ET AL., 2012; EL-HANI; SEPULVEDA, 2009);

b) Religion influences students' academic performance, decision-making, selfesteem and how they perceive certain social issues, such as: morality, ethics and so forth (SANTIAGO, SILVA, BARROSO, 2009; SCHILLINGER-AGATI; LIND, 2003; SOUZA ET AL., 2014).

After the data discussion in this section, the next segment covers the final considerations of this study. 


\section{Final Considerations}

Throughout this paper, I demonstrated how religion is embedded in society, more specifically in education. Such connectedness and hegemony of certain religions have had a substantial impact on the educational context.

In a laic country, the interference of the Church in political issues is quite controversial, as the federal constitution of the country implies complete neutrality as to religious involvement. Conversely, however, the Church has influenced important decisions apropos of political measures that involve abortion, condom use, morning-after pills, same-sex marriage and others.

Society has evolved over time and so has religion. For instance, themes such as position of planets/stars, slavery, women's rights and others have been reviewed. Although society and religion have changed over time, they do not move at the same speed. While society has transformed in some aspects, religion might have not. For examples, issues germane to abortion, condoms and same-sex marriage make the hiatus between the two entities (society-religion) more evident.

From an egalitarian perspective, I understand that everyone has the right to choose whatever religion, beliefs, ideologies they wish to follow. Nevertheless, no religion/belief can be imposed over others as an incontestable truth. In a heterogeneous and laic society, respect for diversity (including race, religion and others) should be an inviolable human right.

With this in mind, it is of paramount importance to argue for the role of education in an individual's life. Based on Freire's perspectives (1996), education is understood as a means for emancipation, autonomy, consciousness, criticalness, and freedom from any form of discrimination and oppression. Additionally, I raised some questions worth debating: Are schools promoting education? Or are they still perpetuating a discourse of oppression/discrimination? Taking this discussion into consideration, I share a question raised by 'Science, Religion, and Development: Promoting a Discourse in India, Brazil, and Uganda', (2010).

Why has a country such as Brazil — that has given rise to one of the most advanced alternatives to the "banking" model of education, that has 
managed to find ways to raise consciousness, that has brought the social dimension of life into education, and that has criticized many of the premises upon which conventional education is based-come to have such problems itself? (p. 37, emphasis mine)

It seems that the word 'problems' in the quotation above answers the questions that I posed: There are problems in the Brazilian educational system. Nevertheless, these problems have always existed. Although pertinent educational perspectives have emerged in the Brazilian context, the educational system is still stuck in traditional patterns, values and beliefs that necessitate being revisited. 


\section{References}

BRASIL. Constituição (1824). Constituição da República Federativa do Brasil. Rio de Janeiro, RJ, Senado, 1824. Accessed on Nov 25, 2016.

BRASIL. Constituição (1988). Constituição da República Federativa do Brasil. Brasília, DF, Senado, 1998. Accessed on Nov 25, 2016.

BRASIL. 1996. Senado Federal. Lei de Diretrizes e Bases da Educação Nacional: $\mathbf{n}^{\circ}$ 9394/96. Brasília, Brasil. Accessed on Nov 25, 2016.

BRIGGS, David. Religion and higher education: The effect on faith of being smarter than a fifth-grader. 2011. Disponível em:

http://www.faithandleadership.com/features/articles/david-briggs-the-effect-faith-beingsmarter-fifth-grader. Accessed on Aug, 20, 2016.

BORG, Simon. Teacher cognition in language teaching: a review of research on what language teacher think, know, believe and do. Language Teaching. Cambridge University Press, v. 36, p. 81-109, dez, 2003.

BRUNEAU, Thomas Christopher. Power and Influence: Analysis of the Church in Latin America and the case of Brazil. Latin American Studies Association, v. 11, n. 2, p. 25-51, 1973.

CARVALHO, Graça. et al. The Influence of Religion on Portuguese and Brazilian Teacher's Conceptions about the Origin of Life. Cultural, Social and Gender Issues. v. 01, n. 01, p. 1-6, 2012.

CUNHA, Clera Barbosa; BARBOSA, Cláudia. O ensino religioso na escola pública e suas implicações em desenvolver o senso de respeito e tolerância dos alunos em relação aos outros a si próprios. Sacrilagens, v. 8, n. 1, 2011, p. 164-181.

DURKHEIM, Emile. The Elementary Forms of the Religious Life. London: George Allen \& Unwin, 1976.

DUARTE; André Luis.; NETO, Luiz Bezerra. Reflexões sobre a influência religiosa nas escolas do campo e de seus intelectuais. Cadernos da Pedagogia. São Carlos, Year 6, v. 6, n. 12, 2013, p. 49-59.

EL-HANI, Charbel Nino; SEPULVEDA, Claudia. The relationship between science and religion in the education of protestant biology preservice teachers in a Brazilian university. Springer Science + Business Media B.V. Vol. 5, n. 1.2009, p.103-125.

EMMERICK, Rulian. As relações Igreja/Estado no Direito Constitucional Brasileiro. Um esboço para pensar o lugar das religiões no espaço público na contemporaneidade.

Revista Latinoamericana, v. 01, n. 5, 2010, p. 144-172. 
FERNANDES, Patricia Lopes. A influência da Igreja Católica na educação pública brasileira através do Ensino Religioso (1889-1937). Campinas, SP. Monografia de graduação.

Universidade Estadual de Campinas, 2008, 77p.

FREIRE, Paulo. Pedagogy of Oppressed. Vol. 10. New York, Penguin Books, 1996, 181p.

GLASS, Gene; MCGAW, Barry; SMITH, Mary Lee. Meta-analysis in Social Research. Beverly Hills, CA: Sage, 1981

HAGOPIAN, Frances. Latin American Catholicism in an age of religious and political pluralism: a framework for analysis. The Helen Kellogg Institute for International Studies, vol. 1 n. 1, 2006, p. 1-33.

KISRT, Michael; WIRT, Frederick. The Political Dynamics of American Education. 4 ed. California: McCutchan Publishing Coporation, 2009, 394 p.

KUHN, Ademildo. A importância do Ensino Religioso no Ensino Médio. Available at http://www.pedagobrasil.com.br/pedagogia/aimportanciadoensinoreligioso.htm. Accessed on May 4, 2014.

LEITE, Luciana Medeiros. Ensino Religioso na Educação: possibilidades de mediação a partir do conceito de diversidade religiosa em uma escola pública do Distrito Federal. 38p. Monografia (Especialização em Educação), Universidade de Brasília. Brasília: Universidade de Brasília, 2015.

LIMA, Joselia Barros Queiroz. Sons do Silêncio: a relação entre igreja católica e educação escolar- um estudo de caso. Revista Vozes do Vale, v. 1, n. 7, maio 2015, p. 1-21.

MAIA E SILVA, Boris Ensino Religioso e Resistência Moral: Dilemas da Implantação da Lei 3459/00 no Rio de Janeiro. Revista Ética e Filosofia Política, n. 15, v. 1, maio 2012, p. 124149.

MAINWARING, Scott. The Catholic Church and Politics in Brazil: 1916-1985. Standford: Stanford University Press, 1986, 325 p.

MENDONÇA, Antônio Gouvêa. O celeste por vir: A inserção do Protestantismo no Brasil. São Paulo: Universidade de São Paulo, 1995, 372p.

SANTIAGO, Izabel Maria de Oliveira; SILVA, Niely Pereira; BARROSO, Vantuil. A Influência da Religião sobre a Construção da Autonomia. Webartigos. Vol. 1, n.1,2009, p-1-13.

SANTOS, Deyse Luciano de Jesus. Igreja, educação e estado: juntos, separados ou tudo "misturado"? O projeto educacional brasileiro e a influência da religião na inclusão das minorias étnicas na escola baiana. In: Congresso Luso Afro Brasileiro de Ciências Sociais. N.01. Olinda. 2011. Anais. Olinda, PE, vol.01. 2011, p. 1-12.

SAVIANI, Dermeval. As concepções pedagógicas na história da educação brasileira. 0 espaço acadêmico da pedagogia no Brasil, vol. 01, n. 01, 2005, p. 1-38. 
SCHILLINGER-AGATI, Marcia; LIND, Georg. Moral Judgment Competence in Brazilian and German University Students. In: Annual Meeting of the American Education Research Association. N. 1. Washington. 2003. Anais. Washington DC, vol. 05, 2003, p. 1-7.

SCHWARTZMAN, Simon. A política da Igreja e a educação: o sentido de um pacto. Religião e Sociedade, vol. 1, n. 134, 1986, p. 108-127.

SCIENCE, RELIGION, AND DEVELOPMENT: Promoting a Discourse in India, Brazil, and Uganda. Institute for Studies in Global Prosperity, 2010.

SILVA, Katiane Martins Barbosa. Do ensino religioso às aulas régias: a transição de uma educação religiosa para um ensino laico. In: II Encontro internacional de história colonial. N. 24. Caicó. 2008. Anais. Caicó-RN. Vol. 9, 2008, p. 1-8.

SILVA, Lucielma Lobato. O ensino religioso nas escolas do ensino modular de AbaetetubaUma educação científica ou catequética? Congresso de Teologia da PUCPR, 10, 2011, Curitiba. Anais eletrônicos... Curitiba: Champagnat, 2011, p. 371-382.

SOUSA, Paulo et al. 2002. A religiosidade e suas interfaces com a medicina, a psicologia e a educação. Available at http://www.unifesp.br/dpsiq/polbr/ppm/especialo7.htm.

Accessed on Apr 4, 2014.

STRAUSS, Anselm; CORBIN, Juliet. Basics of Qualitative Research: Techniques and Procedures for Developing Grounded Theory. 2 ed. Thousands Oaks: Sage Publications, 1998. 380p. 